\title{
Setaria adhaerens (Forssk.) Chiov. (Poaceae), a new alien species in the Croatian flora
}

\author{
Semir Maslo \\ Primary School, Lundåkerskola, Södra Storgatan 45, 33233 Gislaved, Sweden
}

\begin{abstract}
Setaria adhaerens (Forssk.) Chiov. a pantropical plant species present in some parts of the European continent has been recorded for the first time in Croatia in two anthropogenic habitats in Dalmatia and one in Kvarner bay. The paper presents a short morphological description and photographs of the new alien species, as well as its distribution. A determination key is given for the Setaria taxa most frequently found in Europe.
\end{abstract}

Keywords: alien plants, Dalmatia, distribution, morphology, naturalization, Setaria

\section{Introduction}

The genus Setaria P. Beauv. belongs to the tribe Paniceae, subfamily Panicoideae and family Poaceae. There are 115160 species worldwide occurring in tropical, subtropical and temperate regions. A total of 66 species and five varieties are present in the Old World (Morrone et al. 2014). In the European vascular flora eight species have been recorded according to Valdés and Scholz (2009), among which seven are present in Croatia: native S. pumila (Poir.) Roem. \& Schult., S. verticillata (L.) P. Beauv., S. verticilliformis Dumort., $S$. viridis (L.) P. Beauv., and three alien species, S. faberi R. A. W. Herrm. (Dujmović Purgar and Hulina 2004), S. italica (L.) P. Beauv. and S. parviflora (Poir.) Kerguélen (Milović et al. 2010). S. adhaerens has been reported in Europe as native in Corse, Cyprus, Greece, Spain and Turkey (Valdés and Scholz 2009), and as introduced in Belgium with Luxembourg, Germany, Portugal, Sardegna, Sweden and Ukraine (Karlsson 1987, Valdés and Scholz 2009).

\section{Material and methods}

Field work was undertaken in 2000, 2009 and 2017. Digital photographs and GPS coordinates were taken in the field. Identification of the specimens was done according to Henrard (1940), Rominger (1962), Belo-Correia and Costa (1986), Karlsson (1987) and Amigo et al. (1991). The nomenclature follows the Euro-Med checklist (Euro+Med 2006). Collected plant specimens were deposited in Herbarium
Croaticum (ZA) of the Faculty of Science in Zagreb (ZA 44544 and ZA 44545).

\section{Results and discussion}

The species Setaria adhaerens has been discovered in the territory of the Republic of Croatia in the coastal part of Dalmatia and in Kvarner Bay.

Among European species, S. adhaerens is most similar to S. verticillata, which is native in most of Europe (Valdés and Scholz 2009). They differ from all the other European Setaria species by the setae covered with retrorse prickles.

To identify this new species, an adjusted key based on Rominger (1962), Karlsson (1987) and Verloove (2016) is presented here.

1. Bristles below spikelets retrorsely barbed, strongly catching to clothes, animal fur, and with other spikes; inflorescence axis scabrous with minute spinules; annual grasses

1. Bristles below spikelets antrorsely barbed, not catching; inflorescence axis hairy or scabrous; annual or perennial grasses

.3

2. Margin of leaf sheaths glabrous; inflorescence narrowly conical, blades more or less loosely hairy, spikelets $1.5-2.0 \mathrm{~mm}$ long S. adhaerens 
2. Margin of leaf sheaths with long hairs; inflorescence cylindric, blades glabrous, spikelets 2.0-2.2 mm long

S. verticillata

3. Upper lemma strongly transversely rugose; bristles usually yellowish, always at least four below each spikelet ...........4

3. Upper lemma smooth to rugose; bristles very rarely yellowish, usually 3 below each spikelet ....5

4. Annual grasses; spikelets 3.0-3.5 mm long S. pumila

4. Perennial grasses; spikelets 2.0-3.0 mm long .S. parviflora

5. Inflorescence axis scabrous with minute spinules S. verticilliformis

5. Inflorescence axis hairy ...6

6. Leaf blades softly long hairy adaxially; upper glume ca 3/4 as long as upper lemma; upper lemma rugose; panicle nodding from near the base at maturity. S. faberi

6. Leaf blades glabrous; upper glume 3/4 to as long as upper lemma; upper lemma smooth or rugose; panicle erect or nodding from near the base at maturity. ....7

7. Upper lemma smooth and shining, exposed at maturity, not falling off at maturity; spikelets up to $3 \mathrm{~mm}$; panicle often nodding from near the base at maturity, often very large and tick, sometimes branched. S. italica

7. Upper lemma rugose and dull, not exposed at maturity, falling off at maturity; spikelets up to $2.2 \mathrm{~mm}$; panicle erect, rarely slightly nodding, small to moderately large .. ..S. viridis

Setaria adhaerens (Forssk.) Chiov., in Nuovo Giorn. Bot. Ital., nov. ser., 26: 77 (1919) (syn.: S. verticillata subsp. aparine (Steud.) T. Durand \& Schinz), (Fig. 1). Annual, stem branched at the base, $25-60 \mathrm{~cm}$ tall, the culms often geniculate below. The nodes glabrous, leaf sheaths glabrous, the hyaline margins glabrous to the summit. Ligule a ring of stiff, white hairs, 1-2 mm long. Leaf blades flat, 5-10 mm wide, usually less than $10 \mathrm{~cm}$ long, strigose on both surfaces, bearing papillose hairs $1 \mathrm{~mm}$ long. Panicle strongly verticillate, yellowish-green or purplish, tapering above, $2-6 \mathrm{~cm}$ long, the axis retrorsely scabrous-hispid on the angles. Spikelets clustered on short branchlets, bristles about $5 \mathrm{~mm}$ long, retrorsely scabrous to the base. Spikelets 1.5-2 mm long, oblong-elliptic, first glume about $1 / 2$ as long as the spikelet, obtuse, second glume nearly as long as the spikelet (Rominger 1962).

According to Valdés and Scholz (2009) the S. verticillata complex presently contains three species: $S$. adhaerens, S. verticillata and S. verticilliformis. S. verticilliformis differs most conspicuously from other two in the complex by the presence of antrorsely barbed bristles.

The taxonomical status of the species $S$. adhaerens and $S$. verticillata has been the subject of several discussions. Some authors recognize $S$. adhaerens and S. verticillata as one species while others recognize them as two. According to Clay-
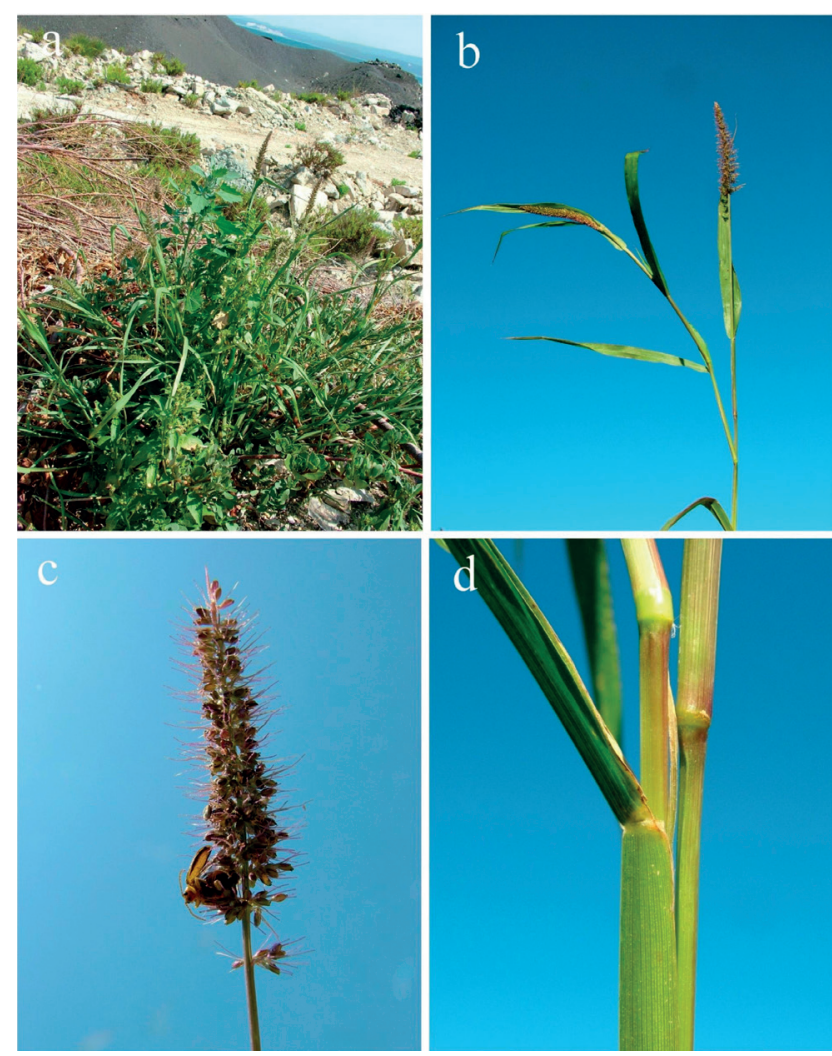

Fig. 1. Setaria adhaerens in the vicinity of the former Dugi Rat carbide and ferroalloys factory near Split, a) habitat, b) upper part of plant, c) panicle, d) leaf sheath (photos by Semir Maslo).

ton (1980), Veldkamp (1994) and Morrone et al. (2014) S. adhaerens is only one of a number of variants of $S$. verticillata that do not seem to merit specific rank, while for other authors (Henrard 1940, Rominger 1962, Scholz 1985, Belo-Correia and Costa 1986, Karlsson 1987, Amigo et al. 1991, Danin and Scholz 1997, Valdés and Scholz 2009, Verloove 2016) they are clearly separate species. The more temperate $S$. verticillata has ciliate sheath-margins, glabrous blades, elongated and cylindrical inflorescence and spikelets over $2 \mathrm{~mm}$ long. The more tropical $S$. adhaerens has glabrous sheath-margins, strigose blades, shorter and clear conical inflorescence (obviously widest at base) and spikelets under $2 \mathrm{~mm}$ long. S. adhaerens also has a shorter panicle, shorter leaves, and a shorter culm height than S. verticillata.

Plants with antrorsely barbed bristles are occasionally found and described as S. adhaerens var. font-queri Calduch (Amigo et al.1991). Recent genetic researches within the Setaria genus indicate that these are two distinct species. Wang et al (2009) pointed out that diploid counts for S. verticillata are most likely misidentified $S$. adhaerens plants. The authors suggest that diploid $S$. verticillata should be named S. adhaerens and the tetraploid form be kept the commonly accepted name of $S$. verticillata.

The first findings of this species for Croatia are from southern Dalmatia, at Veliki Zaton near Dubrovnik in 2000, where it was found in flowerbeds and ruderal places near the local church $\left(42^{\circ} 41^{\prime} 30^{\prime \prime} \mathrm{N}, 18^{\circ} 02^{\prime} 23^{\prime \prime} \mathrm{E}\right)$ and independent- 
ly in the same year from the vicinity of Senj in Kvarner bay $\left(44^{\circ} 57^{\prime} 6^{\prime \prime} \mathrm{N}, 14^{\circ} 55^{\prime} 41^{\prime \prime} \mathrm{E}\right)$; at the motel Kalič; ruderal places, leg. N. Jogan, 19.9.2000 (N. Jogan pers. comm.). Subsequently, the species was also recorded in 2009 in the vicinity of Dugi Rat near Split $\left(43^{\circ} 26^{\prime} 18^{\prime \prime} \mathrm{N}, 1^{\circ} 38^{\prime} 36^{\prime \prime}\right.$ E) (Fig. 2). About twenty specimens were recorded growing on waste places in the area of the former carbide and ferroalloys factory, to-

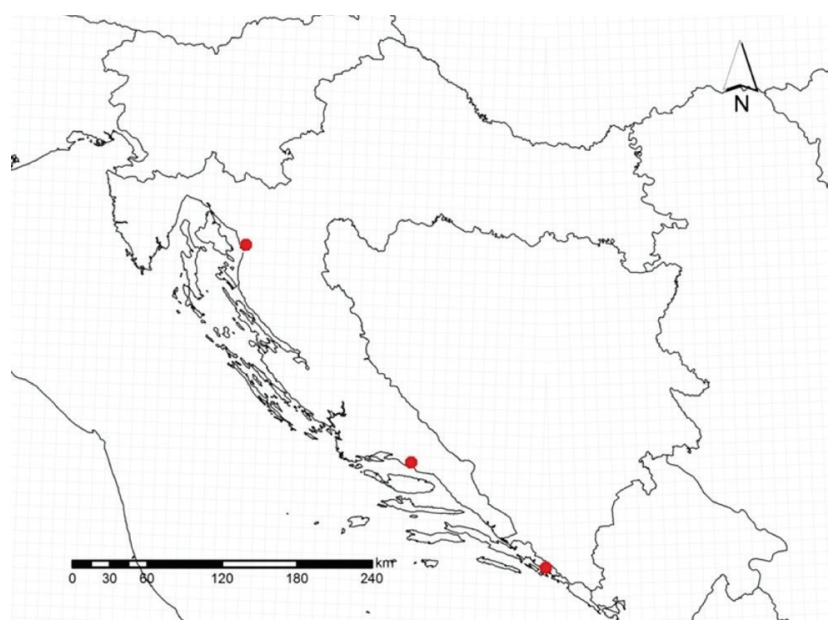

Fig. 2. The distribution of Setaria adhaerens in Croatia.

\section{References}

Amigo, J., Bujan, M., Romero, I., 1991: Révision taxonomique du genre Setaria (Gramineae) dans la Péninsule Ibérique. Bulletin de la Société Botanique de France, Lettres Botaniques $138,155-165$.

Belo-Correia, A. L., Costa, M. F., 1986: Setaria verticillata (L.) P. Beauv. e Setaria adhaerens (Forssk.) Chiov.-I. Revista de Biologia 13, 117-143.

Clayton, W. D., 1980: Setaria Beauv. In: Tutin, T. G., Heywood, V. H., Burges, N. A., Moore, D. M., Valentine, D. H., Walters, S. M., Webb, D. A. (eds.), Flora Europaea. Vol. 5, 263-264. Cambridge University Press, Cambridge.

Danin, A., Scholz, H., 1997: On the occurrence of two taxa of the Setaria verticillata complex in Israel and the Sinai. Willdenowia 27, 177-179.

Dujmović Purgar, D., Hulina, N., 2004: Vineyard weed flora in the Jastrebarsko area (NW Croatia). Acta Botanica Croatica $63,113-123$.

Henrard, J. Th., 1940: Notes on the nomenclature of some grasses. Blumea 3, 411-480.

Karlsson, T., 1987: Setaria adhaerens and S. faberi new species to Sweden. Svensk Botanisk Tidskrift 81, 305-311. (in Swedish).

Milović, M., Mitić., B., Alegro, A., 2010: New neophytes in the flora of Croatia. Natura Croatica 19, 407-431.

Morrone, O., Aliscioni, S. S., Veldkamp, J. F., Pensiero, J. F., Zuloaga, F. O., Kellogg, E. A., 2014: Revision of the Old World gether with some other alien grasses such as: Ceratochloa cathartica (Vahl) Herter, Paspalum dilatatum Poir. and Setaria parviflora (Poir.) Kerguélen. Upon re-visit of the site in July 2017, I observed that the number of individuals was almost unchanged. In my opinion $S$. adhaerens has good prospects of spreading further in Croatia, especially in Dalmatia. Probably it already occurs in the country more widely than the new records indicate, but it is most likely to have been overlooked by collectors because of its similarity to other Setaria taxa, especially $S$. verticillata. It is not entirely clear if the species is originally native there, but in any case there is an appreciable invasion in southern Europe (Amigo et al. 1991). According to Richardson et al. (2000), the observation period is too short to understand and declare a state of naturalized species. Therefore it can be considered a casual alien, probably not yet naturalized, waiting for further field investigations to achieve the proper status attribution.

\section{Acknowledgements}

I would like to thank Nejc Jogan for reporting his own unpublished record, Aldin Boškailo for the mapping of distribution of species as well as Jessica Andersson for improving the English of this paper.

species of Setaria (Poaceae: Panicoideae: Paniceae). Systematic Botany Monographs 96, 161.

Richardson, D. M., Pyšek, P., Rejmánek, M., Barbour, M. G., Panetta, F. D., West C. J., 2000: Naturalization and invasion of alien plants: concepts and definitions. Diversity and Distributions 6, 93-107.

Rominger, J. M., 1962: Taxonomy of Setaria (Gramineae) in North America. Illinois Biological Monographs 29, 1-132.

Scholz, H. 1985: Setaria P. Beauv. In: Davis P. H. (ed.), Flora of Turkey and East Aegean Islands. Vol. 9, 597-600. Edinburg.

Valdés, B., Scholz, H., 2009: Poaceae (pro parte majore). In: Euro+Med PlantBase - the information resource for EuroMediterranean plant diversity. Retrieved September 2017 from http://ww2.bgbm.org/euroPlusMed/

Veldkamp, J. F., 1994: Miscellaneous notes on Southeast Asian Gramineae. IX. Setaria and Paspalum. Blumea 39, 373-384.

Verloove, F., 2016: Setaria Beauv. In: Manual of the alien plants of Belgium. Botanic Garden of Meise, Belgium. Retrieved September 2017 from alienplantsbelgium.be.

Wang, Y., Zhi, H., Li, W., Li, H., Wang, Y., Huang, Z., Diao X., 2009: A novel genome of $C$ and the first autotetrapoid species in the Setaria genus identified by genomic in situ hybridization. Genetic Resources and Crop Evolution 56, 843-850. 